University of Nebraska - Lincoln

DigitalCommons@University of Nebraska - Lincoln

Publications, Agencies and Staff of the U.S.

Department of Commerce

U.S. Department of Commerce

2011

\title{
Fin whale (Balaenoptera physalus) population identity in the western Mediterranean Sea
}

Manuel Castellote

Universidad Complutense de Madrid, manuel.castellote@noaa.gov

Christopher W. Clark

Cornell Lab of Ornithology

Marc O. Lammers

University of Hawaii

Follow this and additional works at: https://digitalcommons.unl.edu/usdeptcommercepub

Part of the Environmental Sciences Commons

Castellote, Manuel; Clark, Christopher W.; and Lammers, Marc O., "Fin whale (Balaenoptera physalus) population identity in the western Mediterranean Sea" (2011). Publications, Agencies and Staff of the U.S. Department of Commerce. 250.

https://digitalcommons.unl.edu/usdeptcommercepub/250

This Article is brought to you for free and open access by the U.S. Department of Commerce at DigitalCommons@University of Nebraska - Lincoln. It has been accepted for inclusion in Publications, Agencies and Staff of the U.S. Department of Commerce by an authorized administrator of DigitalCommons@University of Nebraska - Lincoln. 
MARINE MAMMAL SCIENCE, $* *(*): * * * \_* * *(* * * 2011)$

(C) 2011 by the Society for Marine Mammalogy

DOI: $10.1111 / j .1748-7692.2011 .00491 . x$

\title{
Fin whale (Balaenoptera physalus) population identity in the western Mediterranean Sea
}

\author{
Manuel Castellote ${ }^{1}$ \\ UCM Group for the Study of Animal and Human Behaviour (Gecah), \\ Departamento de Psicobiología, \\ Universidad Complutense de Madrid, \\ Campus de Somosaguas, 28223 Madrid, Spain \\ E-mail: manuel.castellote@noaa.gov \\ Christopher W. Clark \\ Bioacoustics Research Program, \\ Cornell Lab of Ornithology, \\ 159 Sapsucker Woods Road, \\ Ithaca, New York 14850, U.S.A. \\ Marc O. LAmmers \\ Hawaii Institute of Marine Biology, \\ University of Hawaii, \\ Kaneohe, Hawaii 96744, U.S.A. \\ and \\ Oceanwide Science Institute, \\ PO Box 61692, \\ Honolulu, Hawaii 96744, U.S.A.
}

\begin{abstract}
Archival bottom-mounted audio recorders were deployed in nine different areas of the western Mediterranean Sea, Strait of Gibraltar, and adjacent North Atlantic waters during 2006-2009 to study fin whale (Balaenoptera physalus) seasonal presence and population structure. Analysis of 29,822 recording hours revealed typical long, patterned sequences of $20 \mathrm{~Hz}$ notes (here called "song"), back-beats, $135-140 \mathrm{~Hz}$ notes, and downsweeps. Acoustic parameters (internote interval, note duration, frequency range, center and peak frequencies) were statistically compared among songs and song notes recorded in all areas. Fin whale singers producing songs attributable to the northeastern North Atlantic subpopulation were detected crossing the Strait of Gibraltar and wintering in the southwestern Mediterranean Sea (Alboran basin), while songs attributed to the Mediterranean were detected in the northwest Mediterranean basin. These results suggest that the northeastern North Atlantic fin whale distribution extends into the southwest Mediterranean basin, and spatial and temporal overlap may exist between this subpopulation and the Mediterranean subpopulation. This new interpretation of the fin whale population

\footnotetext{
${ }^{1}$ Current address: National Marine Mammal Laboratory, Alaska Fisheries Science Center/NOAA, 7600 Sand Point Way N.E. F/AKC3, Seattle, Washington 98115-6349, U.S.A.
} 
structure in the western Mediterranean Sea has important ecological and conservation implications. The conventionally accepted distribution ranges of northeastern North Atlantic and Mediterranean fin whale subpopulations should be reconsidered in light of the results from this study.

Key words: Balaenoptera physalus, Mediterranean fin whale, North Atlantic fin whale, population identity, bioacoustics.

Fin whales (Balaenoptera physalus L. 1758) are the only commonly observed mysticete in the Mediterranean Sea. Fin whale presence there has been documented since ancient times (Notarbartolo di Sciara et al. 2003), but because of its pelagic distribution, this species is among the poorest known of all cetaceans in the Mediterranean Sea. The status of the Mediterranean fin whale population is of considerable concern, and a better understanding of their population structure is needed in order to assess conservation needs (e.g., Barcelona Convention 1976, Bern Convention 1979, Bonn Convention 1979, Panigada et al. 2005).

No population estimates exist for the entire Mediterranean region. Line-transect surveys yielded estimates of 3,583 fin whales (SE 967; 95\% CI 2,130-6,027) over a large portion of the western Mediterranean in 1991 (Forcada et al. 1996), and 901 (SE 196; 95\% CI 591-1,374) in the Corsican-Ligurian-Provençal basin in 1992 (Forcada et al. 1995). No more recent data are available, so population trends are unknown (Reeves and Notarbartolo di Sciara 2006).

Fin whales in the North Atlantic are classified by the IWC into seven management units, based largely on catch and marking data: Nova Scotia, NewfoundlandLabrador, West Greenland, East Greenland-Iceland, North Norway, West NorwayFaroe Islands, and British Isles-Spain-Portugal (Donovan 1991). However, there is evidence that some movement occurs across the boundaries of these management units, indicating that these units are not completely discrete. The current IWC model proposes seven hypotheses for stock (group of whales from the same breeding ground) structure within these management units. The model assumes a central stock that feeds in the area between East Greenland and the Faroe Islands, a Spanish stock, and under most hypotheses, an eastern stock and a western stock as well (IWC 2010).

Mediterranean fin whales are currently defined as a distinct subpopulation from those in the North Atlantic, perhaps extending out to southern Portugal (IWC 2009). Genetic analyses based on mitochondrial DNA indicated differences between fin whales in the Mediterranean, Atlantic coastal waters of Canada, Greenland, Iceland, and Spain. The Mediterranean subpopulation may be resident, but no differences with Atlantic animals were observed based on nuclear DNA (Bérubé et al. 1998), suggesting a model of geographic isolation between Mediterranean and North Atlantic whales. Other genetic analyses (Palsbøll et al. 2004) better supported a male-mediated, low-recurrent gene flow hypothesis between Mediterranean and northeastern North Atlantic subpopulations.

Results from satellite tagged fin whales and stable isotope analysis from baleen plates suggest that a small proportion of Mediterranean fin whales migrate seasonally through the Strait of Gibraltar to feed in the Atlantic Ocean (Cotté et al. 2009). However, visual observations of fin whales in the Strait of Gibraltar and adjacent waters show different seasonal movements than the general pattern described in the 
western Mediterranean basin (Raga and Pantoja 2004). Therefore, the hypothesized movement of Mediterranean whales into the North Atlantic is not fully supported by either the satellite tag or visual observation data. Few other population marker data are available by which to better evaluate the degree of isolation and current distribution limits of Mediterranean fin whales. As a result, the distribution limits and the relationship between North Atlantic and Mediterranean fin whales are still puzzling, and the identity of observed whales crossing the Strait of Gibraltar remains uncertain.

Multidisciplinary approaches that include both traditional and alternative population markers are improving our current knowledge of the population structure of mysticetes (Donovan 1991, Mellinger and Barlow 2003, Clapham et al. 2008). Alternative population markers include acoustic methods (Mellinger and Barlow 2003, McDonald et al. 2006). Payne and Guinee (1983) first proposed using song characteristics as a means of identifying humpback stocks. The use of song characteristics to describe population affiliation over a broad geographical range has been further extended to additional mysticete whale species including the fin whale (e.g., Thompson et al. 1992, Hatch and Clark 2004, Delarue et al. 2009) and the blue whale (e.g., Ljungblad et al. 1998, McDonald et al. 2006). In species, such as fin whales, where genetic assessment of population structure is hindered by logistic difficulties in collecting sufficiently large sample sizes of tissue, geographic variations in songs may offer a good alternative, provided they track meaningful biological units from a management point of view (Delarue et al. 2009).

Several acoustic parameters of fin whale song have proven to be useful for identifying their populations. In particular, time intervals between $20 \mathrm{~Hz}$ song notes and the frequency range for notes (referred to as note bandwidth) can be used to explain up to $80 \%$ of the song variability between populations in the North Atlantic and North Pacific Oceans (Hatch and Clark 2004). Also, differences in song repertoire have provided a means to differentiate subpopulations in the North Atlantic (Clark and Gagnon 2002) and Southern Ocean (Širovic et al. 2009).

Acoustic methods have already been proposed as a potential tool for cetacean conservation in the Mediterranean Sea (e.g., Notarbartolo di Sciara and Gordon 1997); however, prior to this report, little effort, if any, has been made in this direction. This study uses fin whale song features to identify subpopulations of fin whales in the western Mediterranean Sea, Strait of Gibraltar, and Azores archipelago in order to improve our knowledge of the current population structure in this area. The results presented here can be applied to inform conservation management actions and thereby possibly lead to a reduction in human induced pressures on this endangered species.

\section{METHODS}

To study the acoustic characteristics of Mediterranean fin whales, two types of archival bottom-mounted audio recorders were used. Marine Autonomous Recording Units (MARUs) designed by the Cornell University Bioacoustics Research Program (Clark et al. 2002) were deployed in 2006-2007 and Ecological Acoustic Recorders (EARs) designed by the Hawaii Institute of Marine Biology (Lammers et al. 2008) were deployed in 2007-2009. Recorders were deployed in nine different areas (Fig. 1). There were six deployment areas in the western Mediterranean Sea (Provençal Basin, Cape Begur, Columbretes archipelago, Menorca, Ibiza channel, and Alboran basin), 


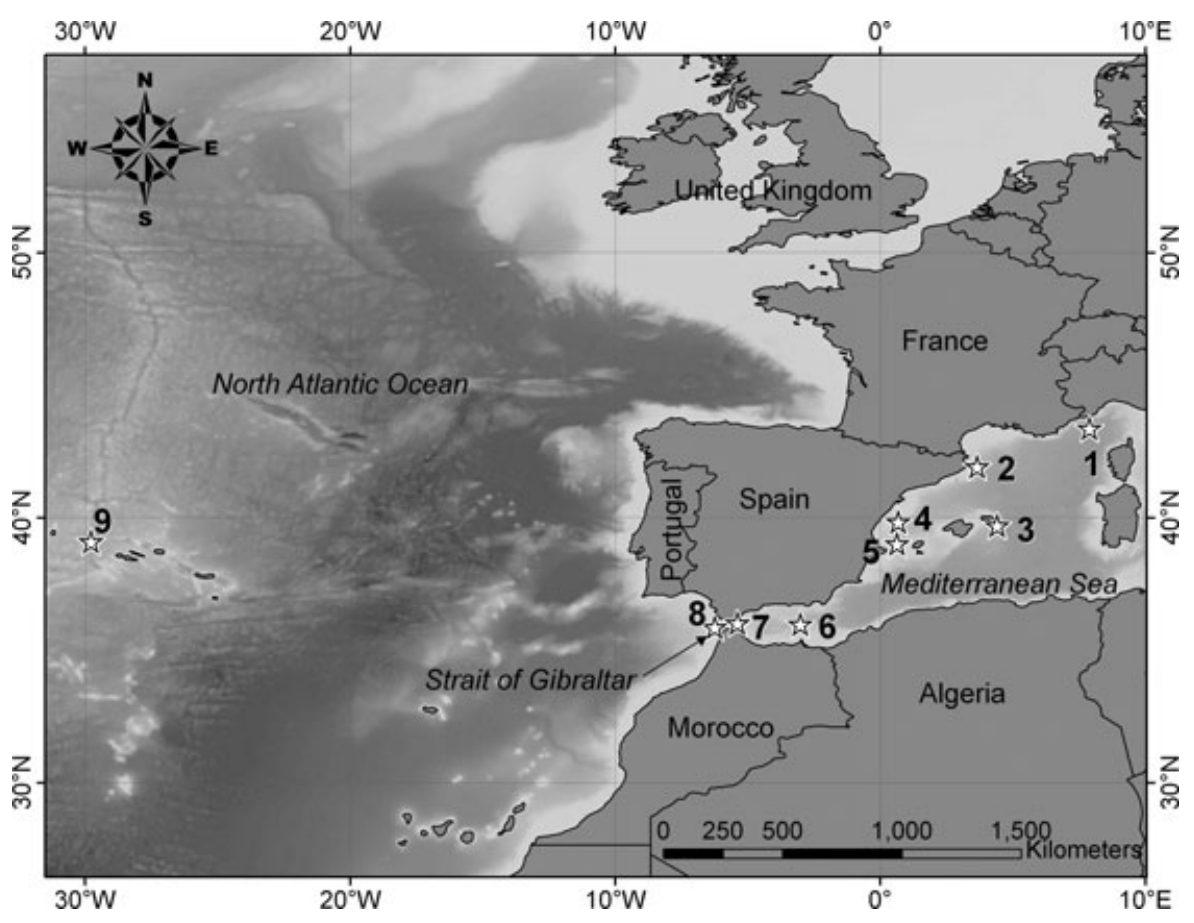

Figure 1. Deployment locations of archival bottom-mounted audio recorders. $1=$ Provençal basin; $2=$ Cape Begur; $3=$ Menorca; $4=$ Columbretes archipelago; $5=$ Ibiza channel; $6=$ Alboran basin; $7=$ Strait of Gibraltar; $8=$ Cape Espartel; and $9=$ Azores archipelago.

two in the Strait of Gibraltar (Cape Espartel and Strait of Gibraltar), and one in the North Atlantic Ocean (Azores archipelago). Overall, there were 12 deployments with an average duration of $3.3 \mathrm{mo}( \pm 0.6 \mathrm{SD})$ throughout a period of $2 \mathrm{yr}$ and $5 \mathrm{mo}$, from August 2006 to January 2009. Three of the 12 deployments failed to obtain data (Cape Begur, Menorca and Cape Espartel) because of water leakage into the housing, analog to digital conversion errors, or loss of the unit. Deployment depths varied between 100 and $1,100 \mathrm{~m}$. MARU sound recordings were continuous and EAR recordings had a $33 \%$ duty cycle ( $5 \mathrm{~min}$ on, $10 \mathrm{~min}$ off). All recordings had a 2,000 $\mathrm{Hz}$ sample rate.

Data recordings were analyzed using the Matlab-based code Extensible Bioacoustic Tool (XBAT, release 5: http://www.xbat.org; Figueroa 2007). An automated detector was implemented in XBAT to search for $20 \mathrm{~Hz}$ song notes in all recordings. We used the definition of song from Watkins et al. (1987), where different songs are separated by silent periods longer than $2 \mathrm{~h}$. Only $20 \mathrm{~Hz}$ notes were included in the analysis as they were the most common and stereotyped, and typically the loudest song note type. All detections were manually validated and false detections were discarded.

Two different data annotation logs were created manually from the detection validation analysis. One log included $20 \mathrm{~Hz}$ notes used to obtain acoustic measurements. The second log included sequences of $20 \mathrm{~Hz}$ notes from the same songs and was used to measure the silent interval between notes, referred to as the internote interval 


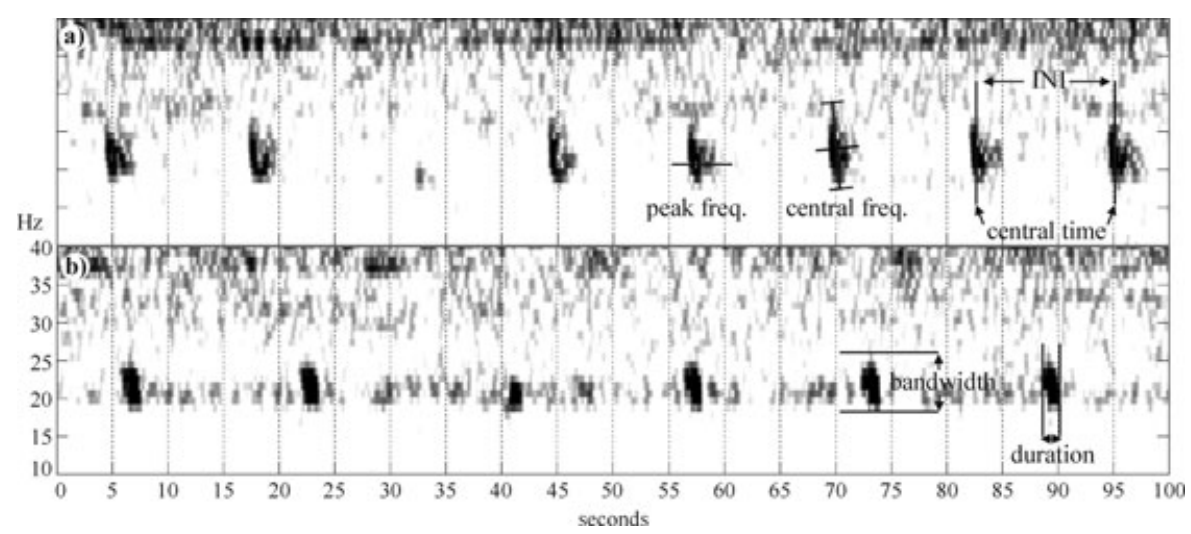

Figure 2. Spectrograms (10-40 Hz, 100 s, 256 FFT, Hanning) of an example of a (a) northeastern North Atlantic song fragment and (b) Mediterranean song fragment with both $20 \mathrm{~Hz}$ notes and back-beats, showing the acoustic measurements for $20 \mathrm{~Hz}$ notes. Note the difference in internote interval and note bandwidth between song fragments.

(INI). The selection criteria were based on (1) $20 \mathrm{~Hz}$ notes with highest signal-tonoise ratio (whales closer to the recorder or low background noise periods in the $20 \mathrm{~Hz}$ band); (2) clarity of note sequence that could unambiguously be attributed to one single whale (e.g., nonoverlapped songs); and (3) $20 \mathrm{~Hz}$ note sequences with a clear structured song pattern (notes organized in sequences produced in long series). Measurements of acoustic events in each log were made using XBAT's Energy Measurement Tool extension. Following the procedures of Hatch and Clark (2004), acoustic characteristics of notes selected for this study were the central frequency, peak energy frequency, note bandwidth, note duration, and central time. INI values were obtained by subtracting the central time of consecutive notes (Fig. 2). All acoustic measurements of each song were grouped together because of the risk of nonindependence of data.

All acoustic measurements grouped by song were explored using a hierarchical regression analysis (Appendix S1) (Bryk and Raudenbush 1987, 1992; Goldstein et al. 1998; Snijders and Bosker 1999). This analysis allows variance in the outcome variables to be analyzed at multiple hierarchical levels, as opposed to a single level as implemented in simple linear or multiple linear regression analyses. Thus, the analysis method here is more appropriate for use with nested data, such as acoustic measurements made on individual $20 \mathrm{~Hz}$ notes that are organized into songs (i.e., note sequences) sung by different whales. Sources of variance are hierarchically organized in different levels. Our model included a first level corresponding to the $20 \mathrm{~Hz}$ song notes and a second level for songs (see online supplemental material). The co-variable "deployment area" was included in the second level to assess its effect on the variability of the acoustic measures of a particular parameter between songs. Differences and similarities in the acoustic parameter measures of songs and song notes between deployment areas were further explored by multiple comparisons using the Bonferroni correction (Snijders and Bosker 1999). To test for a possible confounding effect due to INI seasonal variability, songs recorded when fin whales increase their singing activity (September to January) were compared in the Columbretes archipelago and Alboran basin areas. Kruskal-Wallis statistical analysis 
was used to compare INI from songs from all months between deployment areas and a post hoc Dunn comparison analysis was performed among all groups. Finally, acoustic measurements were grouped into two ocean regions, referred to as Mediterranean and North Atlantic. Song features from these two regions were compared using a one-way analysis of variance (ANOVA).

\section{RESULTS}

A total of $29,822 \mathrm{~h}$ of sound recordings was collected with a total of $103,66420 \mathrm{~Hz}$ notes detected from all deployment areas (Table 1). Other detected fin whale song notes included back-beats and $135-140 \mathrm{~Hz}$ upsweeps, as well as single downsweeps (Fig. 3). The most common song note in all deployment areas was the $20 \mathrm{~Hz}$ note. Back-beats were also common, but were incorporated in songs in smaller proportion (normally 2-5 $20 \mathrm{~Hz}$ notes per back-beat) and sequences without back-beats were also observed in all deployment areas. Interestingly, 135-140 Hz upsweeps were only detected in the Azores archipelago, the Strait of Gibraltar, and the Alboran basin. This was also the case for songs composed exclusively of back-beats, although these were uncommon.

From all the detections, 4,750 $20 \mathrm{~Hz}$ notes from 204 different songs were of high enough quality to be included in the logs for note interval and acoustic parameter measurements (Table 2).

The sample sizes obtained for the Ibiza channel and Alborán basin areas in 2007 were too small to be included in the analysis. Therefore, these data sets were omitted for the hierarchical regression analysis.

The null model of the hierarchical regression analysis explored the statistical significance of acoustic feature variability within and between all songs. The proportion of variance between songs expressed as the intraclass correlation coefficient (ICC), ranged between $43 \%$ and $79 \%$ (Table 3 ). When the deployment area was included in the model's second level as a covariate, a statistically significant effect $(P<0.05)$ was detected for all acoustic parameters and all areas (Table S1). Second-level pseudo- $r^{2}$ values were calculated for each acoustic parameter in order to assess the proportion of variance explained by deployment area. The proportion of variance of song features between deployment areas ranged between $22 \%$ and $96 \%$ (Table 4 ). Since obvious differences in acoustic features were detected between deployment areas, multiple comparisons between areas were performed using the Bonferroni correction (Table S2). Results for INI showed no statistical differences between the data sets from the Azores archipelago, the Strait of Gibraltar, and the 2006 Alboran basin areas. However, INIs from these deployment areas differed from INIs from the Columbretes archipelago and the Provençal basin areas. From all other acoustic parameters, only note bandwidth showed a similar pattern between areas. These two acoustic parameters had the highest pseudo- $r^{2}$ values. All other measured acoustic parameters did not show any other clear relationships between deployment areas.

These data reveal two clear patterns of INI differences and similarities between deployment areas. Songs recorded in areas of strictly Mediterranean influence (Provençal basin and Columbretes archipelago) have INIs of almost $15 \mathrm{~s}$, while songs recorded in deployment areas of North Atlantic influence (Alboran basin and Strait of Gibraltar) or that are strictly in the North Atlantic (Azores archipelago) have INIs of 12-13 s (Fig. 4). 


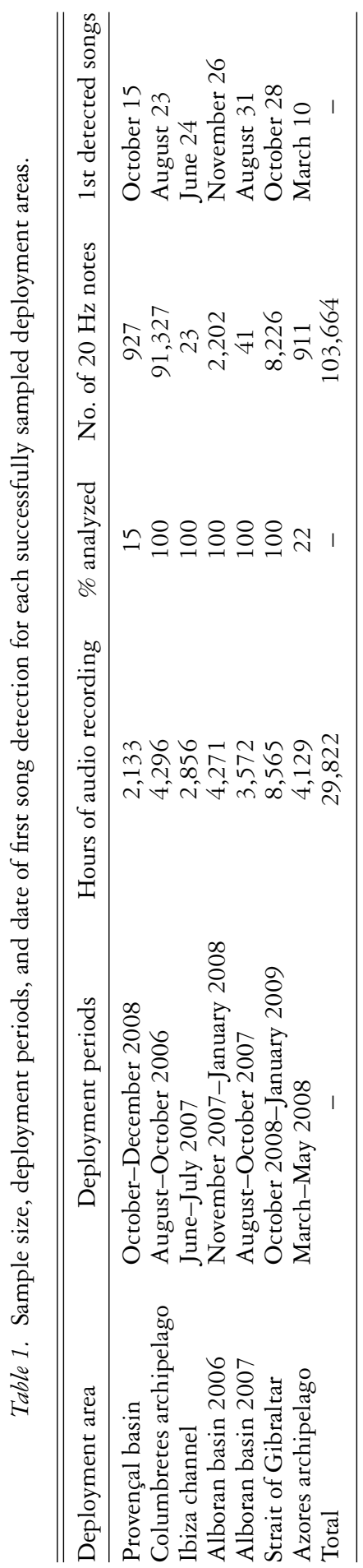




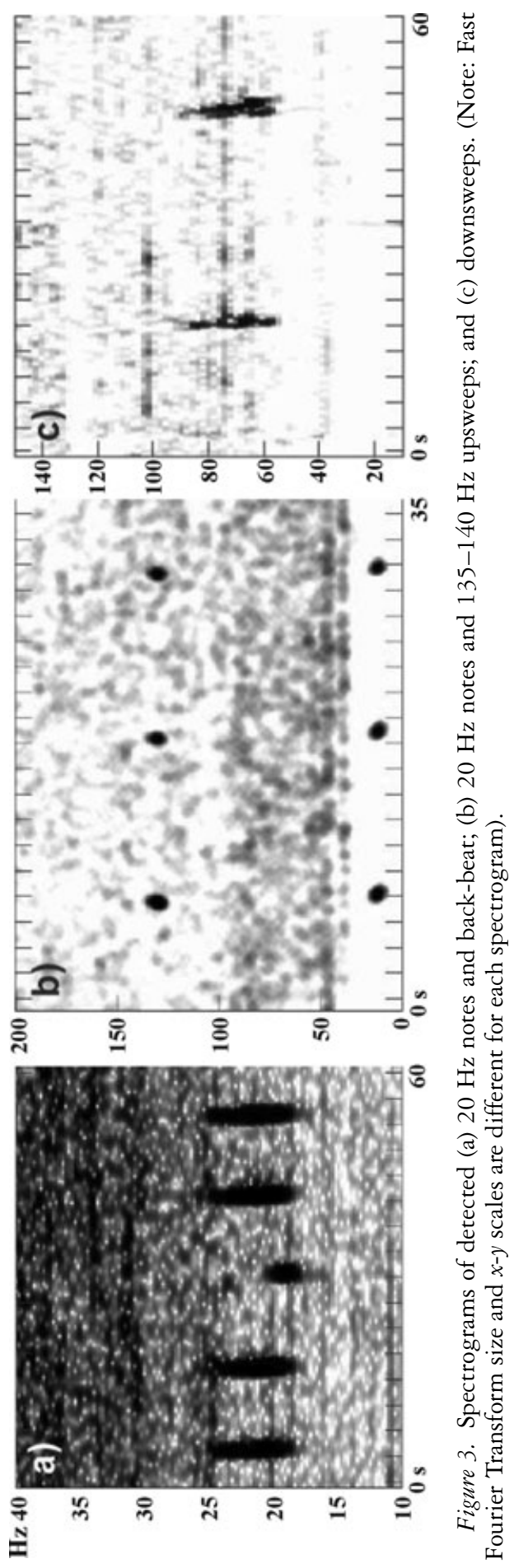




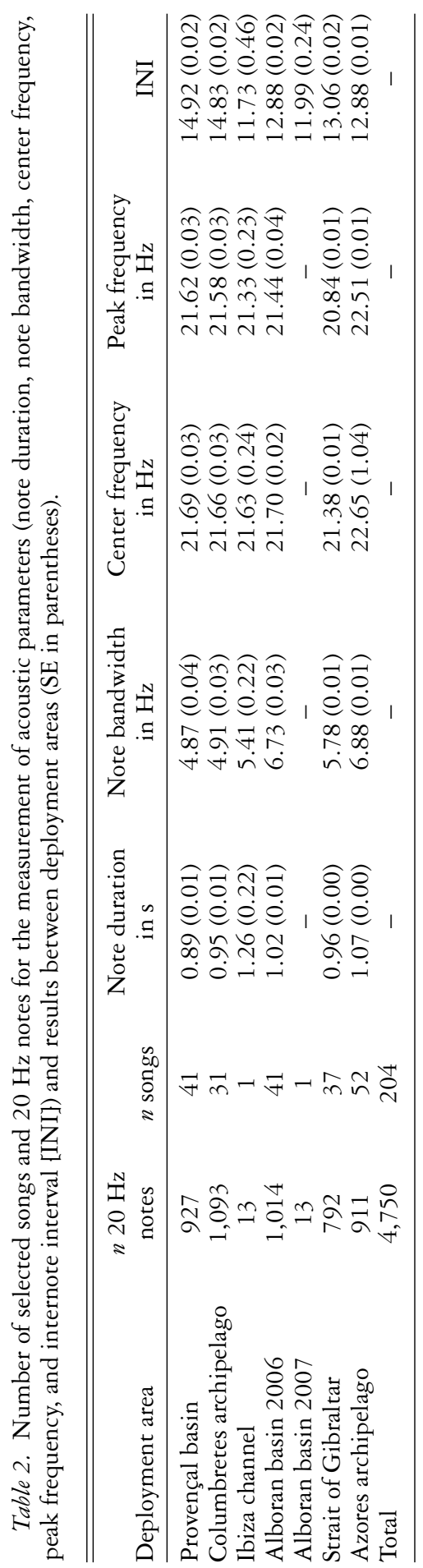


Table 3. Intraclass correlation coefficient (ICC) denoting the variance of acoustic features between songs obtained in the null model from the hierarchical regression analysis.

\begin{tabular}{llll}
\hline \hline Acoustic parameter & \multicolumn{2}{c}{$\begin{array}{c}\text { Variance estimates } \\
\text { (null model) }\end{array}$} & ICC \\
\hline Internote interval & $\hat{\sigma}_{e}^{2}$ & 0.27 & 0.79 \\
& $\hat{\sigma}_{u}^{2}$ & 0.98 & \\
Note duration & $\hat{\sigma}_{e}^{2}$ & 0.02 & 0.48 \\
& $\hat{\sigma}_{u}^{2}$ & 0.02 & \\
Note bandwith & $\hat{\sigma}_{e}^{2}$ & 0.61 & 0.58 \\
& $\hat{\sigma}_{u}^{2}$ & 0.85 & 0.43 \\
Center frequency & $\hat{\sigma}_{e}^{2}$ & 0.56 & \\
Peak frequency & $\hat{\sigma}_{u}^{2}$ & 0.42 & 0.53 \\
& $\hat{\sigma}_{e}^{2}$ & 0.53 & \\
\hline
\end{tabular}

When exploring a possible confounding effect due to INI seasonal variability, no statistically significant differences were found across months within areas of Mediterranean or North Atlantic influence, but statistically significant differences were found for all months between the two regions $(H(4)=470 ; P<0.01)$. These results indicate that for both regions and throughout the period when fin whales increase their singing activity, INI is stable within the same area of influence, but differs between areas of Mediterranean or North Atlantic influence.

Based on the identified pattern for INIs, data sets for all other acoustic parameters were grouped by ocean region and analyzed with one-way ANOVA. Note bandwidth

Table 4. Pseudo- $r^{2}$ estimates for each acoustic parameter based on results from null and fitted models of the hierarchical regression analysis.

\begin{tabular}{lccc}
\hline \hline Acoustic parameter & Model parameter & Variance & pseudo- $r^{2}$ \\
\hline Internote interval & $\hat{\sigma}_{u}^{2}$ null model & 0.98 & 0.96 \\
& $\hat{\sigma}_{u}^{2}$ fitted model & 0.04 & \\
Note duration & $\hat{\sigma}_{u}^{2}$ null model & 0.02 & 0.22 \\
Note bandwidth & $\hat{\sigma}_{u}^{2}$ fitted model & 0.02 & \\
& $\hat{\sigma}_{u}^{2}$ null model & 0.85 & 0.72 \\
Center frequency & $\hat{\sigma}_{u}^{2}$ fitted model & 0.24 & \\
& $\hat{\sigma}_{u}^{2}$ null model & 0.42 & 0.57 \\
Peak frequency & $\hat{\sigma}_{u}^{2}$ fitted model & 0.18 & \\
& $\hat{\sigma}_{u}^{2}$ null model & 0.61 & 0.65 \\
\hline
\end{tabular}




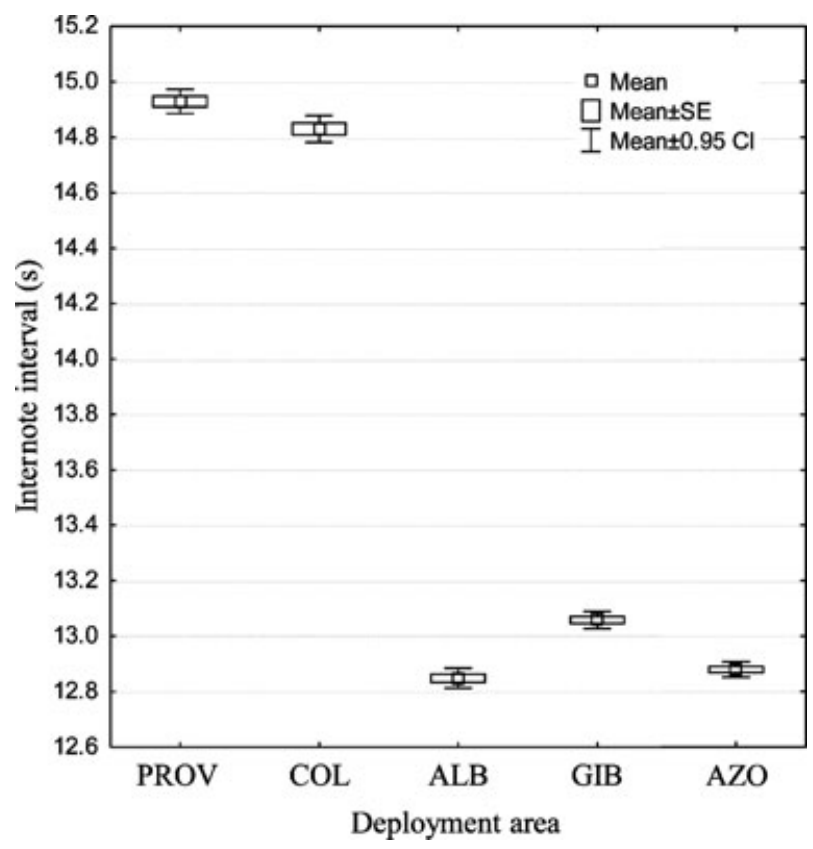

Figure 4. Mean, standard error, and 0.95 confidence intervals for internote interval values (in seconds) from fin whale songs recorded in Provençal basin (PROV), Columbretes archipelago (COL), Alboran basin (ALB), Strait of Gibraltar (GIB), and Azores archipelago (AZO).

and note duration results further revealed significant differences between the two regions, although differences within regions were also statistically significant (Table 5, Fig. 5).

Data sets from the Ibiza channel area and the Alboran basin in 2007 were too small to be included in the hierarchical regression analysis, but some acoustic parameters

Table 5. One-way ANOVA results for all measured acoustic characteristics lumped by ocean region: Mediterranean (MED) and North Atlantic (N. ATL).

\begin{tabular}{llrrrrr}
\hline \hline Acoustic parameter & \multicolumn{1}{c}{ SS } & df & \multicolumn{1}{c}{ MS } & \multicolumn{1}{c}{$F$} & $P$ \\
\hline Note duration & Intercept & 140.87 & 1 & 140.87 & $5,895.61$ & $<0.01$ \\
& N. ATL vs. MED & 0.34 & 1 & 0.34 & 14.16 & $<0.01$ \\
& Error & 103.53 & 194 & 0.53 & & \\
Note bandwidth & Intercept & $4,930.88$ & 1 & $4,930.88$ & $9,239.95$ & $<0.01$ \\
& N. ATL vs. MED & 89.84 & 1 & 89.84 & 168.36 & $<0.01$ \\
& Error & 103.53 & 194 & 0.53 & & \\
Center frequency & Intercept & $71,372.65$ & 1 & $71,372.65$ & $129,151.24$ & $<0.01$ \\
& N. ATL vs. MED & 0.78 & 1 & 0.78 & 1.41 & 0.24 \\
& Error & 107.21 & 194 & 0.55 & & \\
Peak frequency & Intercept & $70,364.30$ & 1 & $70,364.30$ & $84,918.94$ & $<0.01$ \\
& N. ATL vs. MED & 0.01 & 1 & 0.01 & 0.01 & 0.91 \\
& Error & 160.75 & 194 & 0.83 & & \\
\hline
\end{tabular}



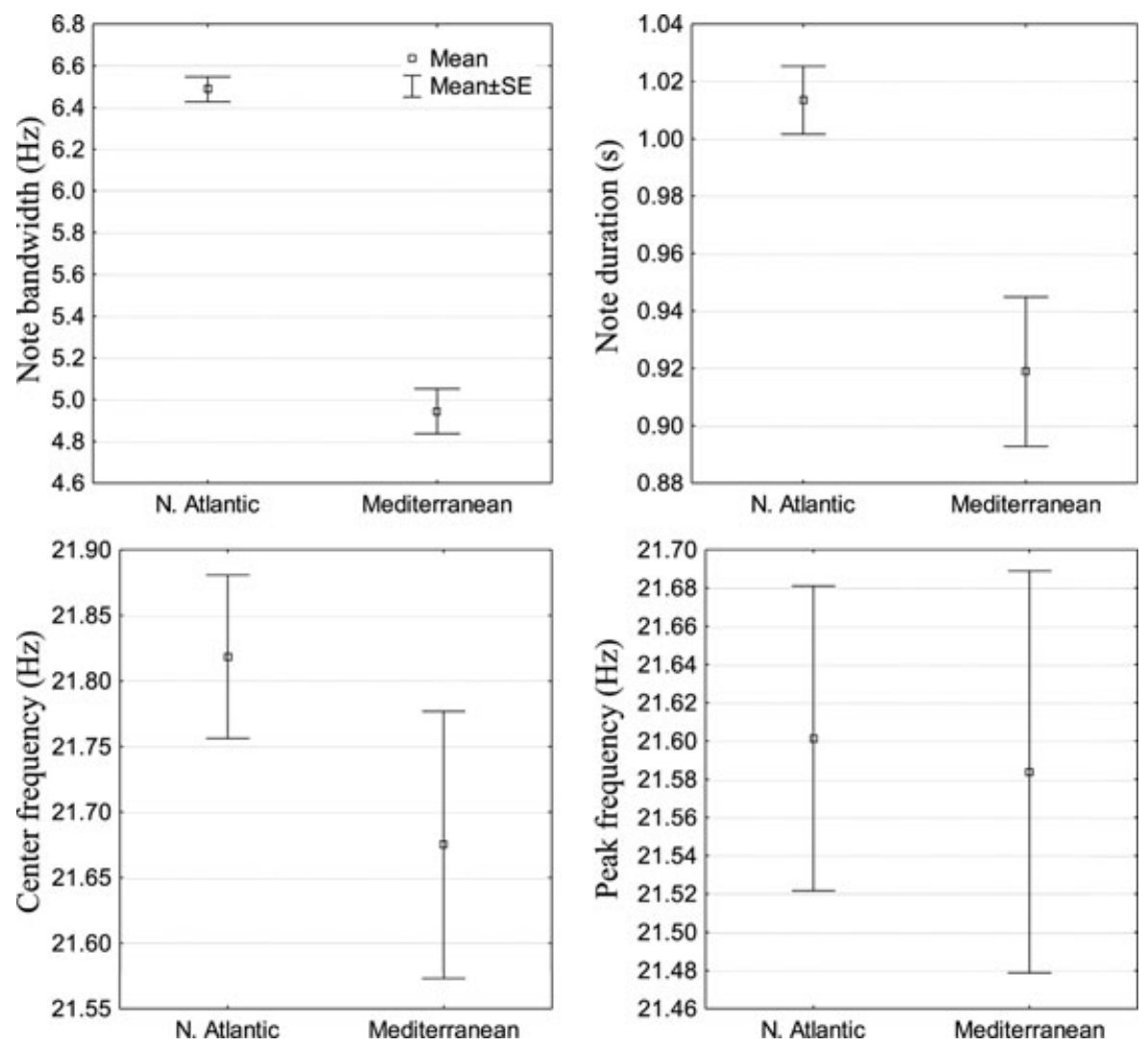

Figure 5. Mean values and standard error of $20 \mathrm{~Hz}$ song note measures lumped by ocean region: Mediterranean and North Atlantic.

were measured. INI was $11.73 \mathrm{~s}(0.46 \mathrm{~s}$ SE) for song recorded in the Ibiza channel and 11.99 (0.55 SE) for the Alboran basin 2007 song. Note bandwidth was $6.41 \mathrm{~Hz}$ $(0.24 \mathrm{~Hz} \mathrm{SE})$ for the Ibiza channel and signal-to-noise-ratio was too low to be measured in the Alboran basin 2007 song recording. The values of these acoustic parameters for both deployment areas matched those of the North Atlantic group.

\section{DISCUSSION}

This acoustic analysis of fin whale song reveals that there are clear and consistent differences between songs from within the Mediterranean Sea and those recorded in the Strait of Gibraltar and in the Azores archipelago. These differences could readily be interpreted as an indicator of two different subpopulations of reproductively active males. However, this acoustic difference does not match the common assumption in the current literature that divides fin whales into a Mediterranean Sea subpopulation and a northeastern North Atlantic Ocean subpopulation (e.g., IWC 2009).

The presence or absence of $20 \mathrm{~Hz}$ notes reflects the presence or absence of male fin whales, respectively, because this is a species-specific and male-specific acoustic 
behavior. Male fin whales are acoustically active throughout large portions of the year with seasonal variability in song production and regional variability in INI and in their regularity of note production and note sequence duration (Watkins et al. 1987, Moore et al. 1998, Hatch and Clark 2004). Therefore, in this study we assumed that acoustic monitoring is a reliable method for establishing the presence or absence of reproductively active male fin whales in a sampled area.

The acoustic presence of fin whales in the Columbretes archipelago area in the fall and their absence in the Ibiza channel in summer matches the well-documented seasonal occurrence of fin whales in their primary feeding ground in Ligurian Sea during summer and subsequent dispersion toward other areas of the Mediterranean basin in early fall (reviewed in Notarbartolo di Sciara et al. 2003). The INIs obtained for these areas in this study are close to $15 \mathrm{~s}$, matching the interval described by Clark et al. (2002) in the Ligurian Sea, which is consistent with the hypothesis that these singers belong to the same Mediterranean subpopulation.

The presence of fin whales in the Alboran basin and the Strait of Gibraltar in fall and winter could be related to the already suggested southward migration of Mediterranean whales from their primary feeding ground in Liguria to southern areas where they spend the winter (Marini et al. 1997). These whales could continue their migration, crossing the Strait of Gibraltar to enter the North Atlantic Ocean, as has been recently suggested by other studies (e.g., Cotté et al. 2009, Gauffier et al. 2009). However, fin whale songs recorded during the fall and winter in the Alboran basin and Strait of Gibraltar have 12-13 s INIs and note bandwidths of $6.5 \mathrm{~Hz}$, and these values are different from those from strictly Mediterranean areas. These two acoustic features match those obtained for songs recorded in the Azores archipelago as well as results from studies from other regions of the North Atlantic Ocean (e.g., Hatch and Clark 2004, Delarue et al. 2009, Simon et al. 2010). Furthermore, the multiple comparison analysis grouped songs from the Alboran basin and the Strait of Gibraltar areas with those from the Azores archipelago and not with songs recorded elsewhere in the Mediterranean. Therefore, our results strongly support the conclusion that fin whale singers in the Alboran basin and Strait of Gibraltar areas during the fall-winter period are associated with a North Atlantic subpopulation different than the Mediterranean subpopulation.

Fin whale songs with Mediterranean acoustic features were never detected in the Alboran basin or the Strait of Gibraltar areas, suggesting that the fall-winter distribution of the Mediterranean subpopulation does not include these regions of the basin. Because Mediterranean fin whales are known to be primarily concentrated in northwestern areas in late spring and summer (Notarbartolo di Sciara et al. 2003), it is improbable that the distribution range of this subpopulation also includes the Alboran basin and Strait of Gibraltar during the late spring-summer period.

The presence of $135-140 \mathrm{~Hz}$ upsweep song notes as well as some songs composed exclusively of back-beats suggest that singers detected in the Azores archipelago, Strait of Gibraltar, and Alboran basin are associated with the northeastern North Atlantic subpopulation, because these particular song notes have been exclusively reported in this region of the North Atlantic (Hatch and Clark 2004). Clark and Gagnon (2002) noted that 135-140 Hz upsweeps were only detected in the northern portion of the North Atlantic Ocean above $55^{\circ} \mathrm{N}$. However, Folkow and Blix (1991) detected this same note type west of Madeira $\left(32^{\circ} \mathrm{N}\right)$ in December 1989 . This observation suggests that northeast North Atlantic male fin whales are present in areas near the entrance to the Mediterranean Sea during winter, supporting our hypothesis. Our results indicate that some male fin whales from the north- 
eastern North Atlantic subpopulation cross the Strait of Gibraltar and enter the Mediterranean Sea, remaining in these areas at least during winter. Results also suggest that males from the Mediterranean subpopulation do not include these areas within their distribution range. Therefore, distribution limits and possible range overlap between males from these two subpopulations must occur within the Mediterranean basin, east of the Alboran basin.

Results from the hierarchical regression analysis shows that $96 \%$ of the INI variation is explained by differences between deployment areas even if there is considerable variation within songs of the same deployment area. From a biostatistical point of view, one single factor explaining such high percentage of variance is extremely rare (Dytham 1999), conveying strong biological significance to the specific time intervals between notes used by fin whale singers. The differentiation between fin whale singers from different regions based on the INI analysis was not so apparent for all other acoustic features explored in the hierarchical regression analysis. In fact, results from using all other acoustic features indicated considerable variance within areas. Between $43 \%$ and $58 \%$ of the acoustic feature variability is explained by song differences in the null model. However, note bandwidth and note duration differences between Mediterranean and North Atlantic songs show statistically significant results. The INI and note bandwidth measures were described as the two more effective parameters for fin whale subpopulation identity within the North Atlantic and North Pacific Oceans (Hatch and Clark 2004).

Songs recorded in the Ibiza channel and Alboran basin in the summer of 2007, although too few to be included in the general analysis, show interesting features. Based on our measured INI and bandwidth values, songs detected in these two areas should be attributed to North Atlantic fin whales. These results support the absence of Mediterranean fin whales in these areas of the Mediterranean basin in summer, in agreement with the proposed hypothesis by Marini et al. (1997), suggesting that Mediterranean fin whales migrate seasonally from northern Mediterranean feeding grounds in the Ligurian Sea to southern Mediterranean breeding areas near the North African continental shelf. Also, summer presence of North Atlantic type singers within the Mediterranean basin emphasizes the importance of the western Mediterranean Sea to this population: males enter the Mediterranean Sea not only in winter but also in summer, and their distribution is not limited to just the Alboran basin. Therefore, distributional overlap between North Atlantic and Mediterranean Sea subpopulations may be higher than previously thought. These observations allow a different interpretation of data obtained by Cotté et al. (2009) and Gauffier et al. (2009). These authors suggest that a small proportion of Mediterranean whales move seasonally into the North Atlantic Ocean to feed. However, an interpretation that agrees more with our acoustic results is that the whales they observed or sampled were North Atlantic individuals seasonally visiting the Mediterranean basin that moved back into the Atlantic Ocean, and did not originate in the Mediterranean.

Visual observations of fin whale movements in the Strait of Gibraltar and nearby areas are consistent with our conclusion that North Atlantic fin whales seasonally enter the Mediterranean basin even if the authors do not suggest it (e.g., Raga and Pantoja 2004). These authors describe a general movement trend toward (but not into) the Atlantic Ocean in spring-summer and toward the Mediterranean Sea during fall-winter. Our acoustic results show that northeastern North Atlantic fin whale males entered the Mediterranean Sea in fall and winter, and the absence 
of acoustic detections in summer suggests that the whales leave the basin by the spring.

Comparative genetic analyses between Mediterranean and North Atlantic subpopulations show a high level of isolation based on mitochondrial DNA, but not nuclear DNA (Bérubé et al. 1998, Palsbøll et al. 2004). Those authors propose that this genetic scenario could be explained by a male-mediated, low-recurrent gene flow between these two subpopulations. This hypothesis is consistent with the acoustic results obtained in this study, which shows that songs from northeastern North Atlantic fin whales have been detected within the Mediterranean basin during breeding season.

An alternative interpretation of our results could be proposed if observed differences in recorded songs did not correspond to a male's membership in a specific subpopulation. In this case, the presence of northeastern North Atlantic songs within the Mediterranean basin in winter could be attributed to Mediterranean males that modified their songs to have northeastern North Atlantic features, thereby increasing their reproductive success when they had access to northeastern North Atlantic females. This hypothesis assumes that fin whale males are able to and do modify their songs to match those preferred by the local female subpopulation. However, none of these characteristics have been described in fin whale acoustic behavior. In fact, their vocal display is more divergent in areas of sympatric populations in the North Atlantic and North Pacific Oceans (Hatch and Clark 2004). Furthermore, this interpretation is not consistent with the high degree of genetic isolation described between Mediterranean and North Atlantic subpopulations (Bérubé et al. 1998) and does not favor a system of song imitation. Also, the observed movement patterns through the Strait of Gibraltar and adjacent waters do not correspond to a subpopulation exchange between basins, but are consistent with a seasonal use by a single population. Therefore, this alternative interpretation of our acoustic results is not supported by the current knowledge on fin whales.

Fin whales were intensively exploited during the past two centuries off the Strait of Gibraltar (reviewed in Aguilar and Borrell 2007) leading some authors to suggest that the use of this habitat has been lost to the population and that this explained the lack of fin whale sightings in the area (Clapham et al. 2008). Our results show that northeastern North Atlantic fin whale songs are abundant and continuously detected throughout the winter in the Strait of Gibraltar.

The current description of fin whale stocks defines a single subpopulation in the Mediterranean Sea (IWC 2009). Our acoustic results strongly suggest that two different subpopulations use the Mediterranean basin. This interpretation has important conservation implications since it implies that the distribution range of Mediterranean fin whales is smaller than previously defined and that two subpopulations are exploiting the same Mediterranean niche, and likely competing for the same resources. Human pressure (in the form of noise and water pollution, for instance) may affect the ecological balance of this competition since the allostatic load of Mediterranean resident whales might be heavier than nonresident North Atlantic whales. Documented differences in chemical contaminant loads between North Atlantic and Mediterranean fin whale samples are an example of this (Aguilar et al. 2002, Fossi et al. 2006).

Our interpretation of the observed differences in the acoustic behavior of male fin whales also has important ecological implications. Two different subpopulations coexist within the Mediterranean basin during the presumed breeding season. The small size of this basin may allow both subpopulations to remain in acoustic contact 
for much of the time. Therefore, an isolation mechanism must be in place other than a physical barrier. Honest singing by males could explain the degree of genetic isolation between both overlapping subpopulations ( $c f$. Stafford 2003 for blue whales). Payne and Webb (1971) hypothesized that, prior to modern ocean shipping, singing fin whales could have been detected across ocean basins based on considerations of song features and the efficiency of very low frequency propagation (Urick 1983). More recently, through the access by some scientists to US Navy SOSUS acoustic data, this hypothesis has been confirmed as fin whale singers have been detected out to distances of many hundreds of miles (e.g., Clark 1995, Clark and Gagnon 2002). Clark and Ellison (2004) presented evidence showing that a combination of songs' features (e.g., very low frequency, intensity, stereotypy, and redundancy) for blue and fin whales are robust against signal degradation. These findings support the conclusion that selective pressures have favored fin whale songs with stereotypic and redundant features, which are honest signals of species and breeding population identity. This communication characteristic has been demonstrated in humpback singers, which produce songs with regionally discriminating features (Payne and Guinee 1983) and sperm whales, which produce coded, rhythmic click patterns that allow group differentiation (Weilgart and Whitehead 1997). This study provides further evidence of honest signaling as part of the mating system on fin whales by highlighting the strong biological significance of acoustic features on male fin whale singing behavior, by identifying statistically significant differences in songs from two sympatric subpopulations and by using song features to describe the population identity of fin whales in the western Mediterranean Sea.

Finally, our results support several hypotheses that have been unresolved for decades. Richiardi (1874) suggested that fin whales were entering the Mediterranean Sea from the Atlantic Ocean. Jonsgård (1966) proposed that fin whales from western Scotland were feeding near the Strait of Gibraltar or even into the Mediterranean Sea. Duguy and Vallon (1976) asserted that some fin whales were resident but others were leaving the basin seasonally. Viale $(1977,1985)$ proposed that whales from northwest Scotland were entering the Mediterranean basin in winter to breed. Despite these numerous reports, suggesting a seasonal entrance of North Atlantic fin whales into the Mediterranean basin, recent literature on the subpopulation identity of Mediterranean fin whales has not considered this hypothesis. The acoustic results presented here provide further evidence that these earlier proposals not only deserve renewed consideration, but could more than likely turn out to be correct.

\section{Conclusions}

Acoustic monitoring of fin whales in the northeastern North Atlantic and the Mediterranean Sea has provided valuable information regarding the population identity of fin whales in this isolated ocean basin. Two well-defined acoustic patterns, based on INI and note bandwidth have been identified allowing the description of two different subpopulations of fin whales within the Mediterranean basin, one resident and the second a seasonal visitor from the northeastern North Atlantic Ocean. This proposed population structure is consistent with current genetic knowledge of Mediterranean fin whales as well as with descriptions of their movement trends in the Strait of Gibraltar and adjacent waters. Northeastern North Atlantic fin whale wintering grounds extend into the southwest Mediterranean 
basin and possibly beyond, and spatial and temporal overlap may exist between this subpopulation and Mediterranean fin whales. This interpretation has important behavioral, ecological, and conservation implications. The current distribution range of these subpopulations should be reconsidered based on the results of this study.

\section{ACKNOWLEDGMENTS}

Prof. Fernando Colmenares, Gecah-Departamento de Psicobiología, Universidad Complutense de Madrid, is deeply acknowledged for his supervision of M.C.'s Ph.D. thesis. Funding and logistic support was received from La Ciudad de las Artes y las Ciencias S.A., Generalitat Valenciana, Parques Reunidos Valencia S.A., Centro de Recuperación de Animales Marinos (CRAM), Consejería de Medio Ambiente de la Comunidad Valenciana, and Consejería de Medio Ambiente de la Junta de Andalucía. We are grateful to Dr. Mónica Silva and Irma Cascão, Institute of Marine Research/Department of Oceanography and Fisheries of the University of the Azores (IMAR-DOP/UAç), for providing acoustic data from the Azores. Field work and data collection in the Azores was funded by the Portuguese Science and Technology Foundation (FCT), under the TRACE project (PTDC/MAR/74071/2006). IMAR-DOP/UAç is the R\&D Unit \#531 and part of the Associated Laboratory \#9 (ISR) funded through the pluri-annual and programmatic funding schemes of FCT-MCTES and DRCT-Azores. Support is specially acknowledged to Dr. Sophie Laran (Centre de Recherche sur les Cétacés-Marineland) who carried on the instrument deployments in the Provençal basin and kindly provided acoustic data for this study. Field work and data collection in the Provençal basin was funded by PELAGOS France, contract \#08.048.83400. Prof. María Victoria Hernández and Prof. José Díaz (U. Complutense de Madrid) supervised statistical analyses and added valuable comments to this work. Dr. José María Cortes (SIDMAR S.A.) supervised and contributed to the design and construction of the mooring lines. We acknowledge Secretaría General del Mar, Ministerio de Medio Ambiente y Medio Rural y Marino for granting permits to deploy acoustic instruments within the Spanish Marine Protected Areas of Islas Columbretes (C. Valenciana) and Isla de Alborán (Andalucía).

\section{LiteratURe Cited}

Aguilar, A., and A. Borrell. 2007. Open-boat whaling on the Straits of Gibraltar ground and adjacent waters. Marine Mammal Science 23:322-342.

Aguilar, A., A. Borrell and P. J. H. Reijnders. 2002. Geographical and temporal variation in levels of organochlorine contaminants in marine mammals. Marine Environmental Research 53:425-452.

Barcelona Convention. 1976. Convention for the protection of the Mediterranean Sea against pollution. 77/585/EEC: Council Decision of 25 July 1977 concluding the convention for the protection of the Mediterranean Sea against pollution and the protocol for the prevention of the pollution of the Mediterranean Sea. United Nations Environment Programme. Official Journal L 240:1-2. Available at http://www.unep.ch/regionalseas/regions/med/t_barcel.htm.

Bern Convention. 1979. Convention on the conservation of European wildlife and natural habitats. Council of Europe. Available at http://conventions.coe.int/treaty/ en/treaties/html/104.htm.

Bérubé, M., F. Larsen, G. Notarbartolo di Sciara, et al. 1998. Population genetic structure of North Atlantic, Mediterranean Sea and Sea of Cortez fin whales, Balaenoptera physalus (Linnaeus, 1758); analysis of mitochondrial and nuclear loci. Molecular Ecology 7:585599. 
Bryk, A. S., and S. W. Raudenbush. 1987. Application of hierarchical linear models to assessing change. Psychological Bulletin 101:147-158.

Bryk, A. S., and S. W. Raudenbush. 1992. Hierarchical linear models: Applications and data analysis methods. Sage Publications, London, UK.

Bonn Convention. 1979. Convention on the conservation of migratory species of wild animals. United Nations Environment Programme. Official Journal L 210:10-22. Available at http://www.cms.int.

Clapham, P. J., A. Aguilar and L. T. Hatch. 2008. Determining spatial and temporal scales for management: Lessons from whaling. Marine Mammal Science 24: $183-201$.

Clark, C. W. 1995. Application of U.S. Navy underwater hydrophone arrays for scientific research on whales. Annex M. Report of the International Whaling Commission 45:210 212.

Clark, C. W., and W. T. Ellison. 2004. Potential use of low-frequency sounds by baleen whales for probing the environment: Evidence from models and empirical measurements. Pages 564-582 in J. Thomas, C. Moss and M. Vater, eds. Echolocation in bats and dolphins. The University of Chicago Press, Chicago, IL.

Clark, C. W., and G. J. Gagnon 2002. Low-frequency vocal behaviors of baleen whales in the North Atlantic: Insights from integrated undersea surveillance system detections, locations, and tracking from 1992 to 1996. U.S. Navy Journal of Underwater Acoustics 52:609-640.

Clark, C. W., F. Borsani and G. Notarbartolo di Sciara. 2002. Vocal activity of fin whales, Balaenoptera physalus, in the Ligurian Sea. Marine Mammal Science 18:281-285.

Cotté, C., C. Guinet, I. Taupier-Letage, B. Mate and E. Petiau. 2009. Scale dependent habitat use by a large free-ranging predator, the Mediterranean fin whale. Deep-Sea Research I 56:801-811.

Delarue, J., S. K. Todd, S. M. VanParijs and L. Di Iorio. 2009. Geographic variation in Northwest Atlantic fin whale (Balaenoptera physalus) song: Implications for stock structure assessment. Journal of the Acoustical Society of America 125:1774-1782.

Donovan, G. P. 1991. A review of IWC stock boundaries. Report of the International Whaling Commission 13:39-68.

Duguy, R., and D. Vallon. 1976. Le rorqual commun (Balaenoptera physalus) en Méditerranée occidentale: État actuel des observations. Rapport Commission International Mer Méditerranée 24:21-24.

Dytham, C. 1999. Choosing and using statistics: A biologist's guide. 1999. Blackwell Science, Oxford, UK.

Figueroa, H. 2007. XBAT. v5. Cornell University Bioacoustics Research Program. Available at http://xbat.org/.

Folkow, L. P. and A. S. Blix. 1991. Norwegian whale sighting and acoustic surveys in the Atlantic Ocean during the winter of 1989/90. Report of the International Whaling Commission 41:531-538.

Forcada, J., G. Notarbartolo di Sciara and F. Fabbri. 1995. Abundance of fin whales and striped dolphins summering in the Corso-Ligurian Basin. Mammalia 59:127-140.

Forcada, J., A. Aguilar, P. Hammond, X. Pastor and R. Aguilar. 1996. Distribution and abundance of fin whales (Balaenoptera physalus) in the western Mediterranean sea during the summer. Journal of Zoology (London) 238:23-34.

Fossi, M. C., S. Casin and L. Marsili. 2006. Endocrine disruptors in Mediterranean top marine predators. Environmental Science and Pollution Research International 13:204-207.

Gauffier, P., P. Verborgh, E. Andreu, R. Esteban, B. Medina, P. Gallego and R. de Stephanis. 2009. An update on fin whales (Balaenoptera physalus) migration through intense maritime traffic in the Strait of Gibraltar. International Whaling Commission document SC/61/BC6, Madeira, Portugal. 4 pp. Available at http://iwcoffice.org/.

Goldstein, H., J. Rasbash, I. Plewis, et al. 1998. A user's guide to MlwiN. Multilevel Models Project, Institute of Education, University of London, UK. 
Hatch, L. T., and C. W. Clark. 2004. Acoustic differentiation between fin whales in both the North Atlantic and North Pacific Oceans, and integration with genetic estimates of divergence. International Whaling Commission document SC/56/SD6, Sorrento, Italy. 37 pp. Available at http://iwcoffice.org/.

IWC (International Whaling Commission). 2009. Report of the First Intersessional RMP Workshop on North Atlantic Fin Whales. Copenhagen, March 31st-April 4th 2008. Journal of Cetacean Research and Management 11(suppl):425-452.

IWC (International Whaling Commission). 2010. Report of the 2nd Intersessional Workshop of the North Atlantic Fin Whale Implementation. Greenland, March 19th-22nd. Journal of Cetacean Research and Management 11(suppl. 2):587-627.

Jonsgård, A. 1966. Biology of the North Atlantic fin whale Balaenoptera physalus (L.): Taxonomy, distribution, migration and food. Hvalradets Skrifter 49:1-62.

Lammers, M. O., R. E Brainard, W. W. Au, T. A. Mooney and K. B. Wong. 2008. An ecological acoustic recorder (EAR) for long-term monitoring of biological and anthropogenic sounds on coral reefs and other marine habitats. Journal of the Acoustical Society of America 123:1720-1728.

Ljungblad, D. K., C. W. Clark and H. Shimada. 1998. A comparison of sounds attributed to pygmy blue whales (Balaenoptera musculus brevicauda) recorded south of the Madagascar Plateau and those attributed to 'True' blue whales (Balaenoptera musculus) recorded off Antarctica. Report of the International Whaling Commission 49:439442.

Marini L., C. Consiglio, A. M. Angradi, et al. 1997. Distribution, abundance and seasonality of cetaceans sighted during scheduled ferry crossings in the central Tyrrhenian Sea: 1989-1992. Italian Journal of Zoology 63:381-388.

McDonald, M. A., S. L. Mesnick and J. A. Hildebrand. 2006. Biogeographic characterization of blue whale song worldwide: Using song to identify populations. Journal of Cetacean Research and Management 8:55-65.

Mellinger, D. K., and J. Barlow. 2003. Future directions for acoustic marine mammal surveys: Stock assessment and habitat use. NOAA OAR, NOAA/PMEL Contribution 2557. 37 pp. Available at http://www.pmel.noaa.gov/.

Moore, S. E., K. M. Stafford, M. E. Dahlheim, C. G. Fox, H. W. Braham, J.J. Polovina and D. E. Bain. 1998. Seasonal variation in reception of fin whale calls at five geographic areas in the North Pacific. Marine Mammal Science 14:617-627.

Notarbartolo di Sciara, G., and J. Gordon. 1997. Bioacoustics: A tool for the conservation of cetaceans in the Mediterranean Sea. Marine and Freshwater Behaviour and Physiology 30:125-146.

Notarbartolo di Sciara, G., M. Zanardelli, M. Jahoda, S. Panigada and S. Airoldi. 2003. The fin whale Balaenoptera physalus (L. 1758) in the Mediterranean Sea. Mammal Review 33:105-150.

Panigada, S., G. Donovan and C. Guinet, eds. 2005. Report of the Joint ACCOBAMS/Pelagos Workshop on Fin Whales in the Mediterranean Sea. Monaco, 12-13 November 2005. 40 pp. Available at http://www.accobams.org/.

Palsbøll, P. J., M. Bérubé, A. Aguilar, G. Notarbartolo-di-Sciara and R. Nielsen. 2004. Discerning between recurrent gene flow and recent divergence under a finite-site mutation model applied to North Atlantic and Mediterranean fin whales Balaenoptera physalus populations. Evolution 58:670-675.

Payne, R., and L. N. Guinee. 1983. Humpback whale (Megaptera novaeangliae) songs as an indicator of 'stocks'. Pages 333-358 in R. Payne, ed. Communication and behavior of whales. AAAS Selected Symposium 76. Westview Press, Boulder, CO.

Payne, R., and D. Webb. 1971. Orientation by means of long range acoustic signaling in baleen whales. Annuals of the New York Academy of Sciences 188:110-142.

Raga, J. A., and J. Pantoja, eds. 2004. Proyecto Mediterráneo: Zonas de especial interés para la conservación de los cetáceos en el Mediterráneo español. Ministerio de Medio Ambiente, Naturaleza and Parques Nacionales, Serie Técnica, Madrid, Spain. 
Reeves, R., and G. Notarbartolo di Sciara, eds. 2006. The status and distribution of cetaceans in the Black Sea and Mediterranean Sea. IUCN Centre for Mediterranean Cooperation, Malaga, Spain. 137 pp. Available at http://www.iucn.org/.

Richiardi, S. 1874. Sulle variazioni individuali della Balaenoptera musculus. Atti della Società Toscana di Scienze Naturali 1:246-259.

Simon, M., K. M. Stafford, K. Beedholm, C. M. Lee and P. T. Madsen. 2010. Singing behavior of fin whales in the Davis Strait with implications for mating, migration and foraging. Journal of the Acoustical Society of America 128:3200-3210.

Širovic, A., J. A. Hildebrand, S. M. Wiggins and D. Thiele. 2009. Blue and fin whale acoustic presence around Antarctica during 2003 and 2004. Marine Mammal Science 25:125-136.

Snijders, T. A. B., and R. J. Bosker. 1999. Multilevel analysis: An introduction to basic and advanced multilevel modeling. Sage Publications, London, UK.

Stafford, K. M. 2003. Two types of blue whale calls recorded in the Gulf of Alaska. Marine Mammal Science 19:682-693.

Thompson, P. O., L. T. Findley and O. Vidal. 1992. $20 \mathrm{~Hz}$ pulses and other vocalizations of fin whales, Balaenoptera physalus, in the Gulf of California, Mexico. Journal of the Acoustical Society of America 92:3051-3057.

Urick, R. J. 1983. Principles of underwater sound. Peninsula, Los Altos, CA.

Viale, D. 1977. Contribution à l'étude des grands cétacés en Méditerranée et sur la côte atlantique d'Espagne. Mammalia 41:197-206.

Viale, D. 1985. Cetaceans in the northwestern Mediterranean: Their place in the ecosystem. Oceanography and Marine Biology Annual Review 23:491-571.

Watkins, W. A., P. L. Tyack, K. E. Moore and J. E. Bird. 1987. The $20 \mathrm{~Hz}$ signals of finback whales (Balaenoptera physalus). Journal of the Acoustical Society of America 82:19011912.

Weilgart, L., and H. Whitehead. 1997. Group-specific dialects and geographical variation in coda repertoire in South Pacific sperm whales. Behavioral Ecology and Sociobiology 40:277-285.

Received: 13 October 2010

Accepted: 6 March 2011

\section{SUPPORTING INFORMATION}

The following supporting information is available for this article online:

Appendix S1: The hierarchical regression analysis model used in this study.

Table S1: Multilevel analysis fitted (study area) and random (song) effect estimates and significance level for all the measured acoustic features.

Table S2: Results from multiple comparison analysis using Bonferroni correction for all five acoustic parameters from songs recorded in all study areas (GIB = Strait of Gibraltar; PROV = Provençal basin; $\mathrm{COL}=$ Columbretes archipelago; $\mathrm{ALB}=$ Alboran basin; $\mathrm{AZO}=$ Azores archipelago). 